\title{
ANALISIS RATIFIKASI ASEAN CHINA FREE TRADE AGREEMENT OLEH INDONESIA DALAM PERSPEKTIF HUKUM INTERNASIONAL
}

\author{
Enni Ekakusumawati \\ Universitas Fajar
}

\begin{abstract}
Abstrak
Indonesia sulit melakukan penundaan isi perjanjian, amandemen dan pengakhiran perjanjin AFCTA, Ketentuan yang paling memungkinkan untuk dilakukan oleh indonesia adalah menggunakan aturan WTO dimana pemberlakuan ini dapat diterapkan bagi negara yang belum dapat mengikuti perkembangan liberalisme perdagangan, aturan ini difasilitasi dengan mekanisme perlindungan seperti anti dumping dan saveguard. Oleh karena itu ketentuan yang dapat digunakan indonesia dalam penerapan ACFTA adalah dengan menerapkan fasilitas saveguard dalam WTO sebagai solusi untuk menyelamatkan kepentingan nasional.
\end{abstract}

Kata Kunci: Ratifikasi, Asean Free Trade Agreement, Hukum Internasional, Perjanjian Internasional.

\section{PENDAHULUAN}

Salah satu bentuk kerjasama yang dilakukan Indonesia adalah perjanjian (agreement) ASEAN dengan China. Perjanjian yang dilaksanakan oleh China dan Indonesia tersebut dikenal dengan, Asean China Free Trade Agreement, atau yang disingkat ACFTA.Perjanjian yang melibatkan beberapa negara Asean dan China tersebut tentu memberikan dampak (effect) yang besar bagi perkembangan perekonomian(development of economy) di Indonesia. Perjanjian ACFTA yang dilakukan antara negara-negara ASEAN termasuk Indonesia menjadi salah satu bentuk penegasan keikutsertaan Indonesia dalam Asean China Free Trade Area (ACFTA).

Pro dan kontra keikutsertaan Indonesia dalam perjanjian tersebut sangat jelas terasa. Pihak yang pro menyatakan bahwa keikutsertaan Indonesia dalam ACFTA tidak berarti ancaman (treatment) serbuan produk-produk China ke Indonesia, tetapi merupakan peluang bagi Indonesia untuk meningkatkan ekspor ke China dan negara-negara ASEAN serta peluang tumbuhnya investor dari negaranegara tersebut yang akan menanamkan modalnya di Indonesia guna membuka lapangan usaha baru dalam menyerap Tenaga Kerja di Indonesia.

Undang-Undang Dasar 1945 telah menegaskan dalam Pasal 11 ayat (2), "bahwa perjanjian internasional yang menimbulkan akibat luas dan mendasar bagi kehidupan rakyat dan atau mengharuskan perubahan atau pembentukan undang-undang, harus dengan persetujuan DPR (hak menyatakan pendapat)." Meskipun dalam pengesahan perjanjian ACFTA dapat dilakukan dengan persetujuan DPR sesuai pasal 11 ayat (2) UUD 1945 dalam hal pembentukan Undang-undang, Namun dalam ketentuan Undang-undang No 24 tahun 2000 secara jelas, juga menegaskan bahwa perjanjian ekonomi internasional(the agreement of international economy) tidak termasuk dalam kesepakatan (consensus) yang harus mendapat ratifikasi dari DPR, sehingga ACFTA merupakan domain eksekutif yang pengesahannya cukup melalui Keppres.

Pentingnya penuntasan masalah perjanjian ACFTA tersebut, menjadi sebuah keharusan pemerintah untuk melihat lebih jauh tentang ketentuan dan prosedur perubahan perjanjian ACFTA 
dengan berpedoman pada Konvensi Wina 1969 tentang hukum perjanjian internasional yang hanya mengatur perjanjian internasional antara negara dan negara saja, dan ketentuan Framework ACFTA.

\section{Metode Penelitian}

Penelitian ini berbentuk penelitian normatif. Pendekatan yang digunakan dalam penelitian ini, yaitu pendekatan perundang-undangan

(statue approach).Pendekatan penelitian ini, fokus penelitian tidak hanya melihat pada bentuk perundang-undangan saja, melainkan juga menelaah materi muatannya, untuk mencari landasan filsufis, dasar ontologis, serta ratio logis lahirnya peraturan perundang-undangan. Dalam Konteks ini ketentuan-ketentuan yang akan dilihat dan dikaji, antara lain ketentuan Perjanjian internasional yang dibuat antara negara diatur dalam Vienna Convention on the Law of Treaties (Konvensi Wina) 1969, dan Ketentuan Undang-undang No.24 Tahun 2000 tentang Perjanjian Internasional serta Ketentuan dalam Perjanjian dalam ACFTA.

Selain pendekatan perundangundangan penulis juga menggunakan pendekatan konseptual (conceptual approach). Adapun yang dimaksud pendekatan konseptual adalah pendekatan yang beranjak dari pandangan dan doktrindoktrin yang berkembang dalam ilmu hukum khususnya di bidang perjanjian internasional

Berdasarkan pendekatan dalam penelitian ini, data diperoleh dari bahan hukum primer, yaitu bahan hukum yang bersifat autoritatif artinya bahan hukum yang bersifat otoritas.Selain itu, data juga di peroleh dari bahan hukum skunder yaitu semua publikasi tentang hukum yang bukan merupakan dokumen- dokumen resmi.

Teknik pengumpulan data yang dilakukan dalam penelitian ini didasarkan pada kebutuhan analisis dan pengkajian. Metode pengumpulan data dilakukan dengan penelitian kepustakaan (library research), dengan mempelajari dan mengkaji sejumlah perundang-undangan, buku-buku teks, catatan-catan resmi atau risalah dalam pembuatan undang-undang, kamus-kamus hukum, jurnal hukum yang dianggap relevan dengan objek penelitian.

Setelah bahan-bahan hukum dikumpulkan dengan menggunakan teknik yang telah ditetapkan di atas, kemudian dilakukan penyusunan secara sistematis terhadap bahan-bahan tersebut. Selanjutnya mengidentifikasikan bahan hukum sesuai dengan kelompok permasalahan yang diajukan dalam penelitian ini.Kemudian dicari interpretasi, selanjutnya dianalisis. Teknik analisis ini dikenal dalam penelitian ilmu-ilmu sosial dengan metode analisis.

\section{ANALISIS DAN PEMBAHASAN Konvensi Wina 1969}

Suatu perjanjian internasional yang sudah berlaku, bahkan sudah diterapkan dengan segala akibat hukumnya, ada kemungkinan sebuah perjanjian itu di amandemen, amandemen atau perubahan perjanjian dalam Konvensi Wina diatur dalam Bagian ke IV yang termuat pada pasal 39 , 40 dan 41. Berkenaan dengan amandemen dan modifikasi atas suatu perjanjian Internasional. Pasal 39 mengatur ketentuan umum tentang amandemen suatu perjanjian internasional, pasal 40 yang terdiri dari lima ayat mengatur tentang amandemen atas suatu perjanjian internasional multilateral, sedangkan pasal 41 terdiri dari (2) ayat, mengatur tentang modifikasi atas suatu perjanjian multilateral hanya antara pihakpihak tertentu yang terikat pada perjanjian internasional multilateral.

Konvensi Wina 1969 mengatur tentang pengakhiran dan penundaan suatu perjanjian internasional dalam $\mathrm{Bab} \mathrm{V}$ diatur tentang penundaan dan pengakhiran perjanjian yaitu dalam dalam seksi 3 tentang penundaan dan pelaksanaan suatu perjanjian internasional yang terdiri dari 11 pasal, yakni pasal 54, 55, 56, 57, 58, 
59, 60, 61, 62, 63, 64. Terakhir adalah seksi 4 tentang prosedur yang terdiri dari 8 pasal yakni, pasal 65, 66, 67, 68, 69 70, 71 , dan 72 .

\section{Undang-undang No. 24 Tahun 2000 Tentang Perjanjian Internasional}

Sejalan dengan makna perjanjian internasional berdasarkan Undang-undang No. 24 Tahun 2000. Perjanjian internasional adalah perjanjian, dalam bentuk dan nama tertentu, yang diatur dalam hukum internasional yang dibuat secara tertulis serta menimbulkan hak dan kewajiban di bidang hukum publik. Pasal 4 Undang-undang tentang Perjanjian Internasional itu bahkan mengikat Pemerintah Indonesia agar berkewajiban melaksanakan perjanjian tersebut dengan itikad baik. Pasal 16 ayat (1) UU No. 24 Tahun 2000 menegaskan, Pemerintah Republik Indonesia melakukan perubahan atas ketentuan suatu perjanjian internasional berdasarkan kesepakatan antara para pihak dalam perjanjian tersebut.

Presiden dapat membatalkan semua perjanjian internasional yang ditandatangani hanya dengan sebuah penerbitan Keppres. Pembatalan perjanjian tersebut, sesuai dengan Undang-undang Nomor 24 Tahun 2000 yang menyatakan Presiden dapat membatalkan dan bisa melakukan perubahan atas suatu perjanjian internasional. Berdasarkan UU Nomor 24 Tahun 2000 tentang Perjanjian Internasional, disebutkan dalam Pasal 16 ayat 3 bahwa perubahan atas suatu perjanjian internasional yang telah disahkan oleh pemerintah dapat dilakukan dengan peraturan perundang-undangan yang setingkat.

Selanjutnya, dalam pasal 16 ayat (4) ditegaskan, dalam hal perubahan perjanjian internasional yang hanya bersifat teknis administratif, pengesahan atas perubahan tersebut dilakukan melalui prosedur sederhana. Di dalam mekanisme fungsi dan wewenang, DPR dapat meminta pertanggungjawaban atau keterangan dari pemerintah mengenai perjanjian internasional yang telah dibuat. Apabila dipandang merugikan kepentingan nasional, perjanjian internasional tersebut dapat dibatalkan atas permintaan DPR, sesuai dengan ketentuan yang ada dalam Undang-undang No. 24 Tahun 2000, yaitu dalam ketentuan pasal 16 ayat (3).

Berdasarkan Pasal 9 ayat (2) Pengesahan perjanjian internasional dilakukan dengan UU atau KEPPRES. Selanjutnya, pada Pasal 10 dinyatakan, Pengesahan perjanjian internasional dilakukan dengan UU apabila berkenaan dengan ruang lingkup hukum publik, selainnya melalui KEPPRES. Oleh sebab itu, dengan adanya pengesahan melalui KEPPRES No. 48 Tahun 2004 tentang kerangka kerja ASEAN-China, maka ketentuan perjanjian ini menjadi hukum nasional, dengan ketentuan prosedur yang dilaksanakan merupakan bagian dari keseluruhan proses pembuatan perjanjian internasional yang bersangkutan.

\section{Undang-Undang Ratifikasi WTO}

Solusi hukum dari permasalahan ini dapat ditemukan dalam aturan WTO. Dalam aturan WTO, negara yang belum dapat mengikuti perkembangan liberalisasi perdagangan difasilitasi dengan mekanisme perlindungan seperti antidumping dan safeguard. Dalam kasus ini, Indonesia dapat memanfaatkan Safeguard WTO untuk melindungi industri domestik dari kerugian akibat serbuan impor dari China.

Mekanisme Safeguard dapat digunakan dalam kasus perdagangan dengan China, Bahkan mungkin memanfaatkan mekanisme ini bisa jadi tidak sesulit yang diduga sehubungan dengan ketentuan khusus dalam Protokol Aksesi China untuk menjadi anggota WTO.Bagian 16 dari Protokol Aksesi China memuat ketentuan Safeguard khusus terhadap produk China yang dikenal dengan istilah China Safeguard.Sejatinya, ketentuan ini lahir sebagai langkah antisipasi terhadap 
kemungkinan kerugian impor yang akan dialami negara-negara anggota WTO dengan masuknya China sebagai anggota.

\section{Ketentuan dalam Framework ACFTA}

Pasal 14 kerangka kerja perjanjian ACFTA yang mengatur soal amandemen. Rumusannya: "The provisions of this Agreement may be modified through amendments mutually agreed upon in writing by the Parties". Dalam rumusan berbeda bermakna sama, Pasal 19 Perjanjian Kerjasama ASEAN-China menegaskan: "This Agreement may be amended by the mutual written consent of the Parties". Jadi, untuk membatalkan perjanjian bukan saja harus ada kesepakatan seluruh pihak, tetapi juga kesepakatan itu dalam bentuk tertulis.Oleh karena itu, penundaan, bila diinginkan, harus melalui dua tahapan.

a. Tahap pertama adalah meyakinkan negara-negara ASEAN agar ASEAN mau meminta penundaan kepada China.

b. Tahap kedua adalah ASEAN yang telah satu suara dalam penundaan untuk Indonesia bernegosiasi dengan China agar Perjanjian Perdagangan Barang ditunda keberlakuannya. Proses ini akan sangat sulit dan memakan waktu, padahal keberlakuan dari Perjanjian Perdagangan Barang saat ini sudah berlangsung.

\section{Mekanisme dan Prosedur untuk Menghadapi Perjanjian ACFTA (Asean-China Free Trade Agreement) Pentaatan Pelaksanaan Sesuai Isi Perjanjian.}

Apabila dikaitkan dengan konsep hukum internasional dengan aspek pembentukan perjanjian internasional berarti setiap negara mempunyai kedudukan sama dalam pembentukannya. Apalagi dengan adanya konsep pacta sunt servanda yang memungkinkan setiap negara mempunyai kesebandingan di dalam pembentukan perjanjian. Diharapkan dengan memahami perkembangan tersebut, konsep hubungan dan kerja sama antar negara dapat diketahui secara jelas pemahaman dan konsep kerangka tujuan yang sebenarnya dari segi yuridisnya.

Indonesia sebagai Pelaksana dalam perjanjian Internasional seperti ACFTA tentu harus memperhatikan asas-asas penting dalam perjanjian Internasional, yang menjadikan Indonesia terikat dalam setiap perjanjian yang telah diratifikasi baik melalui Undang-undang maupun melalui Keputusan Presiden. Pada dasarnya ada dua Asas Penting yang menjadi pedoman pelaksanaan perjanjian:

\section{a. Asas Itikad Baik}

Prinsip iktikad baik ini tidak hanya berlaku dalam pelaksanaan perjanjianperjanjian yang bersifat khusus, tetapi juga berlaku terhadap perjanjian internasional yang berlaku umum seperti Piagam PBB.Penegasan kembali prinsip itikad baik dalam penyusunan konvensi ini adalah penting untuk menjamin ditaatinya suatu perjanjian internasional yang dibuat itu.Selain ketentuan pentaatan perjanjian yang berdasarkan pada Itikad baik setiap pihak juga harus tetap berpedoman dalam hal pentaatan perjanjian dikenal suatu prinsip yang sangat penting, yaitu "Pacta Sunt Servanda" (perjanjian harus ditepati). Prinsip ini sangat fundamental dalam hukum internasional dan menjadi norma imperatif dalam praktek perjanjian internasional.

\section{b. AsasPacta Sunt Servanda}

Asas pacta sunt servanda merupakan salah satu asas hukum yang berada di dalam sistem, karena telah diwujudkan dalam kaidah hukum dari sistem hukum internasional maupun hukum nasional positif. Melalui ketentuan tersebut dimaksudkan bahwa negara-negara peserta perjanjian, terikat untuk memenuhi kewajiban-kewajibannya sebagai konsekuensi dari kedudukannya sebagai anggota dan telah menerima hak-hak dan keuntungan sebagai peserta dalam perjanjian. Ditegaskan pula, bahwa para pihak dalam memenuhi kewajibannya 
harus dilaksanakan dengan berlandaskan pada asas itikad baik.Pemenuhan kewajiban-kewajiban yang demikian didasarkan pada janji mereka, yang diwujudkan dalam bentuk penerimaan (ratifikasi) ACFTA.Inilah cerminan asas pacta sunt servanda dalam perjanjian ACFTA, dan berpasangan dengan asas itikad baik.

\section{Penangguhan}

Pasal penting UU ini adalah Pasal 5. Pasal ini menyatakan, lembaga negara dan lembaga pemerintah, baik departemen maupun nondepartemen, di tingkat pusat dan daerah, yang mempunyai rencana untuk membuat perjanjian internasional, terlebih dahulu melakukan konsultasi dan koordinasi mengenai rencana tersebut dengan Menteri ketentuan tersebuat dijabarkan dalam ayat (1).

Sedangkan dalam Pasal 5 ayat (2) menyatakan, pemerintah RI dalam mempersiapkan pembuatan perjanjian internasional, terlebih dahulu harus menetapkan posisi. Posisi tersebut dituangkan dalam suatu pedoman delegasi RI.Pedoman delegasi RI perlu mendapat persetujuan Menteri. Pedoman harus memuat antara lain, latar belakang permasalahan, analisis permasalahan ditinjau dari aspek politis, yuridis, dan aspek lain yang dapat memengaruhi kepentingan nasional RI.

Penegasan ketentuan lainnya dapat dilihat dalam Pasal 5 ayat (4) menyatakan, perundingan rancangan suatu perjanjian internasional dilakukan delegasi RI yang dipimpin menteri atau pejabat lain sesuai dengan materi perjanjian dan lingkup kewenangan masing-masing. Pasal utama tadi tidak menyebut pihak di luar pemerintah seperti dunia usaha.Persiapan perundingan dalam rapat-rapat antar departemen dihadiri berbagai instansi pemerintah, swasta jarang diundang. Wajar saja perjanjian kerja sama dengan pihak asing atau organisasi internasional di bidang ekonomi atau perdagangan, suara dunia usaha kurang tersalurkan.
Penundaan atas pelaksanaan suatu perjanjian internasional diatur dalam pasal 57, 58 59, 60, dan 61 Konvensi Wina 1969.

\section{Amandemen Perjanjian}

Bagian ke IV Konvensi Wina 1969 yang diatur dalam pasal 39 , 40 dan 41 . Berkenaan dengan amandemen dan modifikasi atas suatu perjanjian Internasional. Pasal 39 mengatur ketentuan umum tentang amandemen suatu perjanjian internasional, pasal 40 yang terdiri dari lima ayat mengatur tentang amandemen atas suatu perjanjian internasional multilateral, sedangkan pasal 41 terdiri dari 2 ayat, mengatur tentang modifikasi atas suatu perjanjian multilateral hanya antara pihak-pihak tertentu yang terikat pada perjanjian internasional multilateral.

Penegasan ini di pertegas dalam Pasal 14 ketentuan ACFTA yang menegaskan bahwa, PerubahanKetentuanketentuan Persetujuan ini dapat diubah melalui amandemen yang disepakati secara tertulis oleh Para Pihak Indonesia dapat menjadikan ketentuan ini sebagai solusi untuk melakukan perubahan dalam perjanjian yang belum mampu diterapkan oleh pihak Indonesia. Pasal 14 Perjanjian hanya memungkinkan amandemen yang harus disepakati seluruh pihak. Negosiasi yang dilakukan pemerintah atas pemberlakuan ASEAN-China Free Trade Agreement (ACFTA) tidak akan mengubah keberlakuan perjanjian internasional tersebut.

Kalaupun China setuju atas usul Indonesia, pembatalan perjanjian tak mungkin dilakukan jika negara anggota ASEAN lainnya tidak setuju. Pemerintah dapat melakukan negosiasi. Tetapi bukan untuk membatalkan perjanjian, melainkan untuk meminimalisir kesulitan yang dihadapi produk lokal akibat perdagangan bebas ASEAN dan China.

\section{Pengakhiran Perjanjian}


Pasal 1 Konvensi Wina menyatakan antara lain bahwa perjanjian internasional adalah suatu kesepakatan internasional yang dibuat negara-negara secara tertulis dan diatur oleh hukum internasional.Indonesia sebagai sebuah negara secara penuh memiliki kewenangan atas perlindungan terhadap hukum nasionalnya, yaitu, pertama, bukti konkret adanya kerugian atau kerusakan produk dalam negeri harus ada. Banyaknya dampak negatif dari pemberlakuan ACFTA dapat menjadi dasar pengakhiran perjanjian ACFTA.

Kedua, Pemerintah harus juga mencabut hukum nasional pemberlakuan ACFTA di dalam negeri, yaitu Keputusan Presiden Nomor 24 Tahun 2004, Indonesia sebagai negara yang menganut aliran dualisme, harus lebih berpedoman pada ketentuan hukum nasional, sehingga pemberlakuan ACFTA juga dapat diakhiri dengan ketentuan hukum nasional.

\section{Penerapan Ketentuan WTO}

Solusi hukum dari permasalahan ini dapat ditemukan dalam aturan WTO. Dalam aturan WTO, Negara yang belum dapat mengikuti perkembangan liberalisasi perdagangan difasilitasi dengan mekanisme perlindungan seperti antidumping dan safeguard. Dalam kasus ini, Indonesia dapat memanfaatkan Safeguard WTO untuk melindungi industri domestik dari kerugian akibat serbuan impor dari China, Dengan mengeluarkan kebijakan safeguard, yakni pengenaan Bea Masuk Tindakan Pengamanan (BMTP). Selain Itu Pemerintah juga dapat menggunakan SNI.

Pada dasarnya penting bahwa kebijakan dan peraturan harus transparan. Di WTO, tujuan ini dicapai dalam dua arah, yaitu 1) pemerintah negara anggota harus menginformasikan kepada sekretariat WTO dan negara anggota lain atas hal-hal yang spesifik, hukum, atau kebijakan perdagangannya melalui notifikasi, dan 2) WTO melakukan tinjauan ulang secara reguler terhadap kebijakan perdagangan suatu negara.
Artikel 20 GATT (General Agreement on Tariff and Trade) mengijinkan pemerintah menggunakan standar dalam regulasi teknis dalam rangka melindungi kehidupan atau kesehatan manusia sebagai proteksi.

\section{A. Penerapan Standar Nasional Indonesia [SNI]}

Safeguard dan SNI adalah dua di antara hambatan perdagangan nontarif yang diizinkan WTO (organisasi perdagangan dunia). Kemudian segera diberlakukan penggunaan Standar Nasional Indonesia (SNI) terhadap produk impor, termasuk produk buatan China yang akan masuk. Selanjutnya, SNI harus diberlakukan terhadap produk-produk buatan pabrik milik perusahaan China yang ada di Indonesia. Penerapan SNI ini penting untuk menciptakan standarisasi produk-produk impor yang masuk ke Indonesia, yang tak kalah penting adalah membenahi faktor-faktor yang menyangkut peraturan dan perijinan, meminimalisir ekonomi biaya tinggi, menurunkan suku bunga kredit, mempercepat pembangunan dan perbaikan infrastruktur, khususnya listrik, jalan, air bersih, dan pelabuhan, kemudian meningkatkan kualitas entrepreneur dan tenaga kerja, teknologi produksi, pemasaran, keuangan, iklim usaha dan investasi.

\section{B. Upaya Mengantisipasi Praktik Dumping}

Kelemahan dari perangkat hukum anti-dumping dapat dilihat dalam PP. 34 Tahun 1995, terkait dengan pengertian harga normal. Salah satu unsur terjadinya praktik dumping apabila harga yang ditawarkan di pasar negara pengimpor lebih rendah jika dibandingkan dengan harga normal (norma value) di dalam negeri pengimpor. Dalam PP. 34 Tahun 1996, Pasal 1 butir 3, yang dimaksud dengan harga norma adalah harga yang sebenarnya dibayar atau akan dibayar untuk barang sejenis dalam perdagangan 
pada umumnya di pasar domestik negara pengekspor untuk tujuan konsumsi.

Berdasarkan kebijaksanaan tersebut di atas, maka untuk melakukan tuduhan dumping harus betul-betul mempunyai bukti yang kuat dan telah memenuhi syarat-syarat yang telah di tentukan oleh WTO. Untuk dapat kenakan bea masuk anti dumping memenuhi syarat yaitu: adanya harga produk yang sama di jual lebih murah di bawah harga domestik negara asal barang, harga itu menyebabkan kerugian, dan adanya causal link antara harga dumping dengan kerugian yang timbul.

\section{Penerapan Safeguard}

Safeguard adalah salah satu mekanisme perlindungan perdagangan yang diperbolehkan aturan WTO. Safeguard adalah tindakan pengamanan perdagangan yang dilakukan suatu Negara untuk melindungi industri domestik dari kehancuran akibat serbuan impor. Safeguard dapat diterapkan dalam kondisi perdagangan yang adil selama perdagangan tersebut membawa kerugian terhadap industri domestik. Dalam penerapan Safeguard, Negara harus melakukan perhitungan ekonomi tertentu atas kerugian dan biaya yang harus ditanggung. Safeguard diterapkan dalam bentuk pembatasan impor melalui instrumen kebijakan seperti pengenaan tarif, kuota, ataupun gabungan keduanya. Safeguard di Indonesia diajukan melalui Komite Pengamanan Perdagangan Indonesia yang berada di Departemen Perdagangan.

Safeguard dapat digunakan oleh anggota Organisasi Perdagangan Dunia (WTO) untuk melindungi industri dalam negerinya dari persaingan bebas, terutama dari serbuan produk yang sengaja dihargai terlalu murah (dumping) maupun produk yang di negara asalnya mendapat subsidi. Mekanismenya bisa melalui penerapan bea masuk impor yang sangat tinggi untuk produk tertentu sampai ke pelarangan impor.

\section{PENUTUP}

1. Ketentuan dan prosedur perubahan perjanjian ACFTA (Asean-China Free Trade Agreement)

Konvensi Wina 1969 mengatur mengenai penundaan, amandemen dan pengakhiran perjanjian internasional.Undang-Undang

Nomor 24Tahun 2000 tentang perjanjian Internasional dalam Bab VI Pasal 18 mengenai berakhirnya suatu perjanjian internasional. Pada Undang-undang No 7 Tahun 1994 Tentang Persetujuan Pembentukan WTO mengatur tentang perlakuan khusus bagi negara berkembang seperti Indonesia untuk menerapkan perlindungan terhadap produksi dalam negerinya, sebagai bentuk penyelamatan perekonomian nasional.

2. Mekanisme dan prosedur yang tepat sebagai solusi untuk menghadapiperjanjian ACFTA (Asean-China Free Trade Agreement) prosedur yang paling memungkinkan dilakukan oleh Indonesia untuk penerapan ACFTA adalah dengan menerapkan ketentuan WTO, yaitu dengan Penerapan SNI, Anti-dumping, dan Safeguard WTO.

\section{Saran}

1. Solusi hukum dari permasalahan penerapan perjanjian ACFTA di Indonesia dapat ditemukan dalam aturan WTO. Dalam aturan WTO Negara yang belum dapat mengikuti perkembangan liberalisasi perdagangan difasilitasi dengan mekanisme perlindungan seperti anti-dumping dan safeguard. Dalam kasus ini, Indonesia dapat memanfaatkan Safeguard dan anti-dumping WTO untuk melindungi industri domestik 
dari kerugian akibat serbuan impor dari China.

2. Sebelum mengesahkan perjanjian internasional di bidang ekonomi atau perdagangan, pemerintah perlu mempertimbangkan dampak perjanjian tersebut. Setiap

3. perjanjian kerja sama di bidang ekonomi atau perdagangan membawa dampak baik atau buruk bagi perekonomian.

\section{DAFTAR PUSTAKA}

Alma Manuputy,et.all. 2008. Hukum Internasional. Makassar: Rechta.

Aswari, A., 2017. Hakikat Perwujudan Kepastian Hukum Bagi Para Pihak Dalam Transaksi Jual Beli Telepon Selular Melalui Media Elektronik. Disertasi, Program Pascasarjana Universitas Muslim Indonesia, Makassar

Barutu, Christhophorus. 2007. Ketentuan Antidumping, Subsidi dan Tindakan Peng-amanan (Safeguard) dalam GATT dan WTO).Cet. I. Bandung: PT. Citra Aditya Bakti

Budiono Kusumohamidjojo.1986. Suatu Studi Terhadap Aspek Operasional Konvensi Wina tahun 1969 Tentang Perjanjian Internasional.Binacipta: Bandung.

Boer Mauna. 2005. Hukum Internasional, Pengertian peranan dan Fungsi dalam Era Dinamika Global. Jakarta: Alumni.

Bruggink, J.H. 1996. Refleksi Tentang Hukum. Alih bahasa oleh Arief Sidharta. Bandung: .Citra Adytia Bakti.

Edy Suryono.1984. Praktek Ratifikasi Perjanjian Internasional di Indonesia. Bandung: Remaja Karya.

Friedman, Lawrence M. 2001.Hukum Amerika Sebuah Pengantar (American Law An Introduction).Second Editon, diterjemahkanoleh Wishnu Basuki. Jakarta: Tatanusa.

Hart, H.L.A 1997.The Concept of Law.Oxford: Nusa Media.

Huala Adolf. 2005.Hukum Ekonomi Internasional, Jakarta:Raja Grafindo Persada. . 2005.Hukum Perdagangan

Internasional Persetujuan Mengenai Tarif dan Perdagangan. Bandung: Iblam. 2005.Penyelesaian Sengketa Dagang dalam World Trade Organization (WTO). Bandung: Mandar Maju.

Ian Brownlie. 1979.Principle of Public International Law.Oxford: University-Press $3^{\text {rd }}$.ed.

Johannes Gunawan. 1993. KUHPerdata Buku III Hukum Perikatan dengan Penjelasan.Bandung: Alumni.

Kansil, C.S.T. 1983 Pengantar Hukum dan Tata Hukum Indonesia, Jakarta: Balai Pustaka .

Kartadjoemena,H.S.2002.GATT dan WTO Sistem Forum dan Lembaga Internasional di Bidang Perdagangan. Jakarta: UI Press.

GATT, WTO dan Hasil Uruguay Round. Cet. Pertama. Jakarta: Universitas Indonesia (UI-Press).

Komar Mike. 1981.Beberapa Masalah Pokok Konvensi Wina Tahun 1969 Mengenai Hukum Perjanjian Internasional.Diktat.

Krasner, Stephen D. 1983. International Regimes (Paperback).New York: Cornell University Press.

Mariam Darus Badrulzaman, et.all. 2001.

Kompilasi Hukum Perikatan. Bandung: Citra Adytia Bakti.

Melda Kamil Ariadno. 2007. Hukum Internasional Hukum yang Hidup.Jakarta: DiaditMedia.

Mochtar Kusmaatmadja. 1983. Politik Luar Negeri Indonesia dan Pelaksanaanya dewasa ini. Bandung: Alumni. 
.1996.Pengantar

Internasional,

Hukum

Binacipta:

Bandung.

Syahmin. 2006. Hukum Kontrak Internasional. Jakarta: Raja Grafindo Persada. 1985. HukumPerjanjian R. Agoes.2002. Pengantar Hukum Internasional.Jakarta: Alumni.

Munir Fuady. 2000.Pengantar Hukum Bisnis. Bandung: Citra Aditya Bakti.

Oppenheim-Lauterpacht.1996.

International Law a Treaties, Longmans Green and Company $8^{\text {th }}$.ed.London: New York Teronto.

Paul Krugman. 2009. The Return of Depression Economics and The Crisis of 2008. New York:Norton Company.

Riduan Syahrani. 2000. Seluk Beluk dan Azas-azas Hukum

Perdata.Bandung: Alumni.

Ridwan Khairandy. 2003. Itikad Baik dalam Kebebasan Berkontrak, Jakarta: Universitas Indonesia.

Robert Gilpin. 1991. International Political Economy. Kendall Stiles dan Tsuneo Akaha (ed.). NewYork: HarperCollins Publishers.

Ruggie, John G. 1993, Multilarealism Matters(ed). New York: Columbia University Press.

Schwarzenberger, G.1967. A Manual of International Law.London: Steven \& Sons, Ltd.

Suharnoko.2004. Hukum Perjanjian Teori dan Analisa Kasus.Jakarta: Prenada Media.

Sood, Muhammad. 2005. Pengantar Hukum Perdagangan Internasional.Cet. Pertama. Mataram: Mataram University Press.

Starke, J.G. 1988. Pengantar Hukum Internasional (1).edisi ke sepuluh. Jakarta: Sinar Grafika. 1992. Pengantar Hukum Internasional (2). Edisi ke Sepuluh. Jakarta: Sinar Grafika.

Internasional Menurut Konvensi Wina 1969.Armico: Bandung.

Ulfah, S., 2018, July. The Absolute Responsibility Principle in Environmental Environment System. In IOP Conference Series: Earth and Environmental Science (Vol. 175, No. 1, p. 012036).

Wayan Parthiana, I.2002.Hukum Perjanjian Internasional Bagian 1. Bandung: Bina Cipta.

2005.Hukum

Perjanjian Internasional Bagian 2.Bandung, Bina Cipta.

INTERNET:

Anonim. 2010. "Implikasi ACFTA di Indonesia" (online) www:http Bisnis Indonesia.com.

2010. "Latar Belakang Perjanjian ACFTA (Asean-China Free Trade Agreement)". (online). http:www.KhodoryBlog.com FTA Asean-China jalan terus." 2009. "Pertentangan Antara Asas Pacta Sunt Servanda Dan Asas Rebus Sic Stantibus". (online).www. Legalitas Org.co.id

Edy Burmansyah-Institute.2010.“ACFTA dan Perlindungan Industri Nasional". Bagian 2.for Global Justice.

Hikmahanto Juwana,2010, Mungkinkah Tunda ACFTA, Www. Kompas.com.

Rosmi Hasibuan. 2010. "Suatu Tinjauan Umum tentang Perjanjian Internasional, hal 2 "(online). www. Legalitas org.

Sjafri Mangkuprawira. 2010. "Acfta dan Kesiapan Sumber daya Manusia". (online). http//www.google.com.

Thalis Noor Cahyadi. 2010 "Acfta Antara Manfaat dan Mudharat”(online). http//www.google.com.

Situs-situs:

www.tempointeraktif.com.

www:http Bisnis Indonesia.com 
www. Legalitas.com

Peraturan Perundang-undangan dan Perjanjian Internasional:

Konvensi Wina Tahun 1969 tentangHukum Perjanjian Internasional.

Undang-undang Nomor 20 Tahun 2004 tentangPerjanjianInternasional.

Naskah Perjanjian ACFTA "Agreement On Trade In Goods Of The Framework Agreement On Comprehensive Economiic Cooperation Between The Association of Association Of Southeast Asian Nation And The Peoples Republic Of China "

Keppres No. 48 Tahun 2004 tentang Pengesahan Framework Agreement On Comprehensive Economic CoOperation Between The Association Of South East Asian Nations And The People's Republic Of China (Persetujuan Kerangka Kerja Mengenai Kerjasama Ekonomi Menyeluruh Antara Negara-Negara Anggota Asosiasi Bangsa-Bangsa Asia Tenggara dan Republik Rakyat China), pada 15 Juni 2004

Instruksi Presiden Republik Indonesia Nomor 2 Tahun 2009 Tentang Penggunaan Produk dalam Negeri dalam pengadaan Barang dan Jasa Pemerintah.

Jurnal, Artikel, dan Karya Ilmiah:

Acmad Zain Umar Purba. 2008. Berbagai Isu Aktual dalam Pelaksanaan Undang-undang Perjanjian Internasional, Dikutip dari Kumpulan makalah dan Bahan Penunjang Seminar Nasional Perjanjian Internasional dan Kedudukannnya dalam Hukum Nasional Indonesia. Bandung. 